\title{
Articles
}

Central European Review of Economics \& Finance

Vol. 19, No. 3 (2017), pp. 57-75. D0I: 10.24136/ceref.2017.013

Małgorzata Ofiarska ${ }^{1}$

\section{OPINIONS OF THE REGIONAL ACCOUNTING CHAMBERS REGARDING THE DOCUMENTS ON THE FINANCIAL ACTIVITY OF THE METROPOLITAN UNION}

\begin{abstract}
Except for one provision, the Act on RACs does not specify the rules and procedure of issuing the RACs' opinions on the documents drawn in the course of financial activity of these unions. In this regard, the provisions of the Public Finance Law and Act on RACs apply, setting out the limits of the RACs' opinion-making activity. The subjects of the opinions are the following: draft resolutions, periodical information and reports, recovery proceedings programmes, other financial documents. In general, the opinions issued by RACs do not contain any content binding for their recipients, but in certain situations specific obligations arise, e.g. to present opinion in a proper term to the proper body, making correction to previously prepared financial documents. In one case the negative opinion revokes the entitlement of the decision-making body of the metropolitan union to adopt the budgetary resolution.
\end{abstract}

JEL Classification Codes: H70, H79.

Keywords: metropolitan union, financial documents, opinions, Regional Accounting Chamber.

\section{Introduction}

The aim of this paper is the analysis of the existing legislation regarding issuing the opinions by the Regional Accounting Chambers (RACs) on the documents drawn with reference to the financial activity of the metropolitan

\footnotetext{
${ }^{1}$ Associate Professor, PhD Habil. Head of the Department of Local Government Law at the Faculty of Law and Administration at the University of Szczecin.
} 
unions and pointing out to the fact that this particular form of third party intervention in the financial independence of those unions is necessary. It has been assumed that all public finance entities, including local government units, shall be treated equally in the light of public finance law. This equal treatment shall be reflected in the solutions regarding issuing opinions on documents referring to the financial matters of the local government units (LGUs) as well as various organizational units created by LGUs, including metropolitan unions. The basic research method shall be the method of legal dogmatics, supplemented with analytical and empirical methods. The scope of study included current legislation, legal academics and jurisdiction withe reference to the RACs' opinion-making activity regarding various financial matters of the new local government unit, i.e. metropolitan unions.

The provisions of the Metropolitan Unions Act dated 9 October 2015 have remained effective since January 1, 2016 (Act of 9 October 2015). This is not a legal act of a complex nature, as it does not contain all regulations referring to different aspects of the metropolitan unions functioning. Its internal structure results from repetition of the concept previously applied in so-called local government system acts (Act of 8 March 1990) providing general regulations on, among others, LGUs tasks and their scope of activity, the structure and competence of their organs, principles of making local enactments, the property and finances of LGUs, supervision on their activity. Likewise, the metropolitan unions, which constitute entities classified as local government sector, have been regulated in a separate act.

The legal status of a metropolitan union is specified by the provisions of Article 1,2 and 5 and Article 9 item 2a of Public Finance Law of August 27,2009 . Those provisions specify metropolitan union as the association of LGUs located within a particular metropolitan area, constituting a spatially coherent impact zone of the city being a seat of voivode or regional assembly, characterized by strong functional relations and advancement of urban processes, with at least 500.000 inhabitants. Metropolitan union comprises the communes located within the boundaries of the metropolitan area and poviats which include at least one commune located within the boundaries of the metropolitan area. Metropolitan union is a legal person performing public tasks on their own behalf and at their own responsibility and their independence shall be protected by the courts.

Thus, the essence of a metropolitan union is its being clearly distinguishable from the LGUs forming this union. Such distinction may be of formal and substantial legal nature. The attributes of this distinction are, among others, the bodies of the union being different from the bodies of the LGUs forming 
this union, the catalogue of union's own tasks, statutory sources of union's income and revenues, own budget of a metropolitan union and different financial plans (e.g. long-term financial forecast), budgetary reporting of the union separate from the budgetary reporting of the LGUs forming the union.

The need to create legal basis for the creation of metropolitan unions has been reported by the local government circles and academics for many years. It has been pointed out that it is necessary to reinforce the current structure of the public administration in its local dimension with the entities capable of satisfying effectively the collective needs of the inhabitants of the communes, entwined with the neighbouring LGUs to form a single organism through a network of mutual dependencies stemming from functional, economic and cultural relations (Dolnicki, 2016, p. 563). In view of the regulations of the Public Finance Law, metropolitan unions have the legal status of the units of the public finance sector. In accordance with Article 4 section 2 Public Finance Law, the provisions of this Act regarding LGUs shall apply accordingly to these unions, including the provisions regulating issuing opinions by RACs.

\section{The essence and scope of the opinion-making activity of the Regional Accounting Chambers}

The term „opinion" has been widely used in the acts regulating the status, tasks and functioning of RACs, however the term was not defined by the legislator. According to dictionaries, an opinion - (French: opinion) is an assumption, outlook, information, decision (oral or written) regarding the value and merits of someone or something, the assessment, reference (Dubisz, 2003, pp. 237-238) or reputation (Bańko, 2005, p. 495). A similar term, though not used in the legislation regarding RACs, is "consulting", which may denote seeking opinion of a specialist, expert or a person of trust, giving advice and providing explanations by a specialist or expert (Bańko, 2003, p. 672). Thus, it shall be assumed that "to issue an opinion" shall be associated with such actions as: to review, express an opinion, asess, consult (Bańko 2005, p. 495). An opinion-maker is a person or institution authorized to issue opinions on something or someone (Dubisz, 2003, p. 238) on the grounds of having necessary knowledge or experience (Bańko, 2007, p. 368). An opinion-making body may be, for example, a body or entity whose task is issuing opinions on something or someone (Bańko, 2007, p. 368).

The task of RAC directly expressed by the legislator is developing opinions on the matters specified in the enactments (Act of 7 October 1992, Article 1 
section 3). However, further provisions of the Act on RACs, as well as the Public Finance Law, contain the term „issuing an opinion”. Dictionary definition of "developing” specifies it as „working on something and giving it a defined shape" (Bańko, 2007, p. 374). Thus, developing an opinion does not necessarily involve presenting other entity with this opinion. Issuing an opinion (previously made and developed) is related with presenting it to a specified recipient who is located outside the organizational structure of the RAC. (Ofiarska \& Ofiarski, 2013, p. 247). Opinions issued by RACs may be considered a tool for preliminary review of the whole process of financial management by the local government, i.e. from the stage of financial planning to the acknowledgement of the fulfilment of duties by the executive bodies (Jurewicz, 2015, p. 115).

The scope of RACs' opinion-making activity regarding metropolitan unions is specified in three enactments. Pursuant to the provisions of the Public Finance Law, RACs issue opinions on:

- possibility of repayment of the credit or loan and redemption of securities taken out or issued by the union;

- draft resolution on long-term financial forecast for the union, or draft of amendment of this resolution;

- the correctness of the planned amount of the union's debt resulting from the planned and incurred liabilities,

- draft budget resolution of the union,

- recovery proceedings adopted by the union,

- possibility of financing the deficit presented by metropolitan union;

- annual report on the execution of union's budget;

Moreover, pursuant to Article 23 section 3 Metropolitan Union Act, RAC issues an opinion on the conclusions made by the audit committee of the union's assembly, regarding the acknowledgement of the fulfilment of duties by the union board. The scope of RACs' opinion-making activity is also specified in the Act on RACs. It is comparable with the scope specified by the provisions of Public Finance Law, however the Act on RACs also mentions the opinions issued with reference to the information on the current budget execution in the first six months filed by the union board.

Various documents created within the framework of the financial activity of the metropolitan union are also subject to the opinions issued by RACs. These include: draft resolutions, annual reports on the execution of union's budget, recovery proceedings programmes, semi-annual information on the budget execution, conclusions by the audit committee of the union's assembly regarding the acknowledgement of the fulfilment of duties by the 
union board, forecasts regarding the possibility of loan (credit) repayment or redemption of debt securities, forecasts regarding servicing of public debt and budgetary deficit of the metropolitan union. The aforementioned documents refer to both the preliminary stage of the financial activity of the union (forecasts, projects), and the stage summarizing the given period of this activity (reports, information, conclusions of the audit committee). Those documents may also be classified taking into consideration the criterion of frequency - how often they are drawn and the opinions are being issued on them. Based on this criterion, it is possible to distinguish the following categories of issuing opinions on documents: periodically, i.e. each calendar year (draft resolutions, annual reports, semi-annual information); intermittent, i.e. not every calendar year (forecasts regarding the planned public debt or budgetary deficit); in extraordinary circumstances (recovery proceedings programmes).

The opinions issued by RACs are generally not binding for the bodies of a metropolitan union or third parties to such union (e.g. banks or other financial institutions), however the legislator has specified such a manner of presenting this information and time of notifying certain bodies and entities, that the contents of particular opinions may have a significant impact on the actions taken by these bodies (entities), as well as on the decisions made by these organs (bodies). Thus, the non-binding nature of RACs' opinions should be analysed taking into consideration the manner of their presentation. It should also be noted that the content of the opinion is the outcome of the works of an expert body having insight in the whole financial economics of the metropolitan union. The opinions are formulated by RACs based on the criterion of legality. All RACs' activities related to the functions they serve (supervisory and monitoring) is based on this criterion (Sawicka, 2013b, p. 50).

Pursuant to Article 14 and Article 15 Act on RACs, the RAC's body is defined as a committee comprising chairman of the chamber acting as the President of the committee and other members appointed by Prime Minister upon the request of the president of the chamber. The members appointed from the candidates proposed by the decision-making bodies of the LGU constitute half of the chamber's committee. The statutory scope of duties of the RAC's committee includes issuing opinions on matters specified in the acts. This task is executed by the adjudicating panel of three, composed of the members of the RAC's committee. The opinions of the adjudicating panel take the legal form of resolutions passed by absolute majority of votes, with at least half of the members of the committee present. The resolutions are executed by a person chairing the meeting of the committee. It is possible 
to appeal against the decisions of the adjudicating panel to the RAC's committee en banc within 14 days from the day of serving the resolutions In the event of appeal against the decision of the adjudicating panel, the task of the committee is to consider the appeal against the opinion, and not to deal with the claims already processed by the adjudicating panel (Resolution of RAC in Bydgoszcz, 2004).

\section{RACs' periodical opinions on the the financial documents of the metropolitan union}

It should be noted with reference to the aforementioned classification of the financial documents of metropolitan union that each year the following documents are subject to opinion by RACs: draft budgetary resolutions of the union, draft resolutions on long-term financial forecasts, information on the execution of union's budget in the first six months of the year, annual reports on execution of the union's budget along with the information on the condition of the union's property, conclusions made by the audit committee of the union's assembly regarding the acknowledgement of the fulfilment of duties by the union board.

Pursuant to Article 238 Public Finance Law, the board of the metropolitan union is obliged to draw a draft budgetary resolution of the union and present it to the union's assembly and RAC no later than November 15 of the year preceding the budget year. Issuing an opinion on the presented draft budgetary resolution is a task of the RAC. The opinion of RAC is a document which significantly affects the course of legislative works of the union's decision-making body aimed at passing the budgetary resolution (Gorgol, 2014a, p. 1147). Legal academics specifies the significant function of such opinion, namely being an instrument of preliminary audit, aimed at preventing the law-making body from adopting the budget in the form that is contrary to applicable norms (Salachna, 2013, p. 941). The RAC's opinion is not binding for the body adopting the budgetary resolution, however the union board is obliged to present it to the union's assembly before adopting the budget.

Article 238 section 3 Public Finance Law indicates that every opinion (positive or negative) issued by the RAC on a draft budgetary resolution must be presented by the executive body (board) to the decision-making body (assembly) of the union. This duty was stipulated differently in Article 21 section 1 Act on RACs, as only the negative opinion on draft budget should be presented to the decision-making body before adopting the budget (together with reply to all allegations included in the opinion) by the executive 
organ. The legislator does not refer to the positive opinion issued by RAC in the quoted provision. Moreover, the legislator points out that issuing negative opinion on the draft budget does not withhold the procedure of budget adoption. Provisions of Article 238 section 3 Public Finance Law and Article 21 section 1 Act on RACs have different scope, as the first one refers to any opinion of the RAC, whereas the second provision refers only to the negative opinions issued by RAC. Moreover, the objects of opinions are specified in a different manner $t$ in each of them. Article 238 section 3 Public Finance Law uses the term „draft budgetary resolution”, whereas a much narrower term „draft budget” is used in Article 21 section 1. Pursuant to the provisions of Public Finance Law, the budget of metropolitan union is the annual plan of income and expenses, as well as the revenues and disbursements of the union. Budgetary resolution consists of a budget and appendices containing the summary of the planned amounts of subsidies granted from the union's budget, the income plan of the income statement of the metropolitan budget units conducting activity in the field of education and the expenditures financed using this amounts, plans of the revenues and costs for the enterprises owned by local government.

The law academics generally state that every opinion issued by the RAC, either positive or negative, on draft budgetary resolution should be presented to the decision-making body by an executive body, and, in the case of a negative opinion being issued by the RAC, the executive organ is also obliged 0 present the decision-making body with replies to allegation contained in this opinion (Sawicka, 2013b, p. 53). The adopted budgetary resolution should be audited by the RAC, which, in the course of supervisory proceedings, indicates inaccuracies and the means and manner of their removal. Should the competent body fail to remove inaccuracies in a specified period of time, the RAC's committee adjudicates invalidity of the resolution in full or in part. It is highly probable that if significant inaccuracies were indicated in the previously issued opinion and the said inaccuracies have not been removed during legislative works on a draft budgetary resolution, the RAC shall deem the resolution invalid in part or in full (Salachna, 2013, p. 942). Shall the budgetary resolution be deemed invalid in part or in full, the budget or the parts of the budget affected by invalidity shall be adopted by the RAC committee.

The provisions of Article 230 Public Finance Law clearly indicate that it is only the board of the metropolitan union that is granted initiative in the matter of drawing a draft resolution on a long-term financial forecast of the union (as well as entitlement to amend it). The draft resolution, including draft resolution amending the long-term financial forecast, is presented for 
opinion together with draft RAC budgetary resolution by the union board. Opinion on a draft resolution on a long-term financial forecast of the union or its amendment is issued by the RAC with special emphasis on ensuring the compliance with the provisions of the Act regarding the adoption and execution of the union's budgets in the next years, including liabilities already incurred or planned. The RAC opinion issued regarding that matter is not read out during the budgetary session of the union's assembly(Resolution of RAC in Zielona Góra, 2010), it is subject to Article 246 section 2 Publice FinanceAct, applicable accordingly, thus the RAC's opinion is published by the metropolitan union within 7 days from the day of receiving it form the RAC The opinion is publishedin accordance with the rules set out in Act of September 6, 2001, on access to public information (Act of 6 September 2001), i.e. the official online journal defined as Biuletyn Informacji Publicznej [Public Information Bulletin].

Pursuant to Article 230a point 1 Public Finance LAw, RACs were obliged to hand the projects of long-term financial forecasts together with the opinion results in the form of an electronic document to Minister of Finance no later than on December 31 of the year preceding the budget year (Resolution of Minister of Finance of January, 2013). This provision entered into force on January 1, 2013 and it is aimed at providing Minister of Finance with greater scope of information on the anticipated financial situation of LGUs and their unions (Leńczuk, 2014, p. 1118).

The scope of RACs duties, specified in Article 230 section 4-5 Public Finance Law include issuing opinions on the correctness of the planned debt amount of the metropolitan union resulting from the incurred and planned liabilities. The opinion is drawn based on the long-term financial forecast adopted by the union and on the budgetary resolution. Shall the RAC's opinionbe negative, the union is obliged to introduce such changes to the resolution, that the union continues to be able to pay its liabilities in a given budget year: loans and credit instalments, redemption of securities and liabilities arising from the sureties and guaranties granted by the union. Capability of regulating the liabilities is established pursuant to the provisions of Article 243 Public Finance Law. Using the plural form "resolutions” in Article 230 section 6 Public Finance Law indicate the obligation to make amendments both to the resolution regarding the long-term financial forecast and budgetary resolution (Walasik, 2011, p. 48).

Article 230 Public Finance Law stipulates that RAC participates in the procedure of adopting long-term financial forecast for the metropolitan union through execution of certain audit tasks in the form of an opinion. There are 
two types of opinions, as the first one refers to the assessment based on the criterion of conformity with the law of the draft resolution regarding the long-term financial forecast, whereas the other opinion refers to the correctness of the planned amount of the union's debt and budgetary resolution (Sawicka, 2013a, p. 72). It has also been noted that the existing provisions of law do not directly specify the general competence of RAC as for the assessment of the validity of the forecasts included in the long-term financial forecast. It is assumed that they may provide assessment of the formal "validity" of the long-term financial forecast, i.e. examination of the conformity of the numbers adopted for the forecast with the ones adopted in the budget and with the data specifying the numbers of previously incurred liabilities, as well as the examination of the aforementioned conformity of the resolution on long-term financial forecast with the statutory requirements (Srocki 2014, p. 8).

Pursuant to the provisions of Article 266 Public Finance Law, no later than on August 31, the board of the metropolitan union presents the assembly of this union an RAC with:

- information on the execution of the union's budget,

- information on the long-term financial forecast, including the process of realization of the long-term programmes, projects or tasks (including the ones related to programmes financed with European funds and agreements on public-private partnership),

- information on the execution of the financial plan for the first six months of the year (specifically with account for the status of receivables and Iiabilities, including the due ones), independent public health care institution, local government culture institutions, local government legal persons whose founding body is the metropolitan union.

The scope and form of this information is specified by the union's decision-making body (assembly). The absence of even one of the necessary elements in the contents of the decision-making body resolution regarding the scope and form of the information shall result in the resolution being incomplete (Resolution of RAC in Lublin, 2012) and make it impossible to control the process of carrying out the targets contained in the financial plans of the union or its organizational units. Pursuant to Article 13 point 4 Act on RACs, only the information on execution of the union's budget in the first six months of the year is the subject of RAC's opinion. The rest of the aforementioned information does not formally constitute the subject of RAC's opinion, however their content may be used by the RAC to form opinions regarding the information on union's budget execution in the first six months (Salachna, 
2010, p. 386). It is possible to appeal against the resolution of the adjudicating panel of the RAC committee regarding such opinion within 14 days from the day of serving the resolution. The appeal shall be considered by the RAC's committee no later than within 14 days from the date of its lodging.

Pursuant to article 267 Public Finance Law the board of the metropolitan union presents to the assembly, no later than on March 31 of the year following the budget year, annual report on the execution of the union's budget, containing summary of income and expenses resulting from closing of the union's budget accounts, no less detailed than specified in budgetary resolution. Within the same time frame, the union's management board presents this report to the RAC in order to obtain an opinion. By issuing the opinion on the budget execution report, the RAC's committee adjudicating panel directly affects the factual and legal situation of the executive body. The union's management board, being the recipient of the opinion concerning the category of financial matters the board is responsible for, has the sole authorisation to lodge an appeal against the decision of the RAC committee adjudicating panel (Resolution of RAC in Warsaw, 2011).

Pursuant to Article 21 section 2 and 3 Act on RAC, the chairperson of the RAC informs the voivode and Minister of Finance about the negative opinion issued regarding the annual report on the execution of the budget. RAC's negative opinionregarding the reporton the execution of the union's budget is presented by the union's management board to the union's assembly together with a reply to objections raised in the opinion no later than the day the fulfilment of duties by the union's management board is acknowledged. Article 21 Public Finance Law does not specify the form in which the execution body is obliged to reply to claims formulated in the negative opinion issued by RAC. The most correct form would be a written reply presented at the session of the decision-making body and then constituting an appendix to the minutes from the budgetary session. However, as the written form has not been specified y the legislator as mandatory, the executive body may give oral reply to the claims contained in the opinion. The oral reply should be recorded in the minutes of the budget session (Decision by Voivodship Administrative Court in Łódź, 2015).

Pursuant to Article 270 section 2 and 3 Public Finance Law, the union's audit commission reviews, among others, considers the report on budget execution together with RAC's opinion on this report and presents the union's assembly with the motion to acknowledge the fulfilment of duties by the union's management board, no later than on June 15 of the year following the budget year. No later than June 30 of the year following the budget year, the 
union's assembly adopts a resolution on the acknowledgement of the fulfilment of duties by the union's management board, following examination of the report on union's budget execution, the RAC's opinion on this report and the opinion of the audit commission. The opinion (conclusion) of the union's assembly audit commission regarding the acknowledgement of the fulfilment of duties by the union's management board is subject to opinion by RAC, pursuant tot the provisions of Article 23 section 3 Metropolitan Union Act.

RAC's opinion on the execution of the budget is not binding and claiming otherwise would be a violation of the rules of the sole competence of the decision-making body to the review the report on the execution of the budget and the resulting acknowledgement of the fulfilment of duties. RAC's opinion is a source of knowledge aimed at providing information useful for the assessment of the execution of the budget (Chruściel \& Kotowski, 2012, p. 65). The acknowledgement of the fulfilment of duties constitutes the summary of the execution of the budget. It is the element closing the financial economics of the union and a measure of control over the union's board by the union's assembly (Decision by Voivodship Administrative Court in Kielce, 2013). The acknowledgement of the fulfilment of duties is an act made by the decision-making body, approving the financial activity of the executive body. The acknowledgement may not be related to any assessment other than the assessment of the board's activity connected directly with the execution of the budget. In the course of the acknowledgement process, clear information regarding the degree of completion of the planned income, expenses, revenues and expenditure shall be obtained, the reasons for discrepancies shall be explained and the question if it is the board who is responsible for such discrepancies shall be answered. The resolution regarding the acknowledgement of the fulfilment of duties must be strictly the outcome of carrying out assessment of the execution of the budget (Resolution of RAC in Opole, 2012).

\section{RACs' occasionally issued opinions on the documents regarding the financial documents of the metropolitan union}

Opinions may be issued by RACs only occasionally, i.e. Following the particular event, thus not every calendar year. They may refer to the union application for a loan or credit or the intention to issue securities, forecast regarding the planned public debt or budgetary deficit of the union.

The obligation of the board of the metropolitan union to obtain the RAC's opinion results from the provisions of Article 91 section 2 Public Finance Law. The obligation arises only when the union is applying for a loan or a credit 
or loan or intends to issue securities whose proceeds are to be spent on financing the planned budget deficit of the union, repayment of earlier obligations with respect to the issue of securities and loans and credits, preceding financing activities financed from the EU budget, financing investment spending and investment purchases included in the framework of multiannual programmes, projects or tasks. The union's management board shall apply to RAC for issuing the opinion. In their opinion, the RAC indicates the possibility of loan or credit repayment or redemption of securities by the metropolitan union.

The need to draw the opinion by RAC, expressed in Article 230 section 4 Public Finance Law, results from planning the debt of the metropolitan union, arising from planned and incurred liabilities contained in the long-term financial forecast. In such circumstances, the amount of metropolitan union's debt and the means of its repayment shall be specified for each year of the financial forecast. Pursuant to the long-term financial forecast adopted by the union and budgetary resolution, the RAC present sthe opinion on the correctness of the planned amount of union's debt. In the event of RAC's issuing negative opinion in this regard, the metropolitan union amends the resolution in such manner, that the union's ability to pay its obligation in a given budget year is preserved. This means the negative opinion issued by the RAC obliges the union's bodies to commence certain legislative actions, i.e. Preparing draft amendments to the resolutions by the union's board and adopting those amendments by the union's assembly. Thus, it may be concluded in such context that the negative opinion issued by the RAC results in the union's bodies taking the actions specified in Article 230 section 5 Public Finance Law.

Shall a deficit be planned in the draft budgetary resolution of the union, the RAC, pursuant to the provisions of Article 246 Public Finance Law, shall present their opinion on the possibility of financing the deficit based on this draft. The RAC's opinion is published by the metropolitan union in public information bulletin [Biuletyn Informacji Publicznej] no later than 7 days from the day of receiving the opinion from the RAC. Further opinion by RAC regarding the possibility of financing the deficit is presented pursuant to budgetary resolution adopted by the union's assembly. This means RAC issues an opinion on financing the deficit twice: once based on the draft budgetary resolution and the second time on the ground of the adopted budgetary resolution. Thus, despite the fact both opinions are issued by the same body, the factual and legal substantiation of the issued opinions is different in each case (Gorgol, 2014b, p. 1197). 
The legislator has specified a finite list of sources of funding the metropolitan union's deficit. Pursuant to Article 217 Public Finance Law Budgetary deficitmight be financed with the revenues from: selling the securities issued by the union, credits, loans, privatising the union's assets, surplus of the union's budget from the previous years, spare funds being the surplus cash on the union's budget current account, resulting from the settlements of the issued securities, credits and loans from the previous years. Wrong indication of the source of addressing the deficit in the budgetary resolution constitutes a breach of law (Resolution of RAC in Katowice, 2016).

\section{RACs' opinions on the documents regarding the financial documents of the metropolitan union issued in extraordinary situations}

A situation may be deemed extraordinary in the event of the metropolitan union not being able to adopt neither the long-term financial forecast, nor the budget that would provide stabilization and liquidity, or in the occurrence of threats to the realisation of public tasks by the union. The provision regulating the actions taken in the aforementioned events was added to Article 240a Public Finance Law on December 28, 2013. It normalized the procedure of presentation and realization of the recovery proceedings and substitutive establishment of the local government budget by RACs. Shall it prove impossible to adopt a long-term financial forecast or the budget of the metropolitan union fulfilling the standards set out in Article 242-244 Public Finance Law and the realization of the public task by the union is threatened, the RAC committee is obliged to request the union to develop and adopt the recovery proceedings programme and hand the programme to the RAC for opinion within 45 days from the day of receiving the request. The union's assembly adopts the recovery proceedings programme for the period not exceeding 3 consecutive budget years.

Article 13 point 13 Act on RACs states that the RACs' scope of duties include issuing opinions on recovery proceedings programmes. It has been assumed that the RAC's opinion on such programme is a supervisory measure and the only criterion for issuing the opinion - similarly to the case of potential threat to realisation of the public tasks - must be the recovery programme's being in compliance with the law (Bitner 2016, p. 691) within the meaning of the programme fulfilling the formal and material standards specified in Article 240 Public Finance Law. Such a specific assessment of the nature of the RAC's opinion on recovery proceedings programme might 
be affected by the suggestions made by the drafter of the act amending Public Finance Law. It has been pointed out that as RACs supervises the financial economics of the LGUs, it is also the RACs' task to issue opinions on the recovery proceedings programmes developed by LGUs (Explanatory statement on a bill dated November 8, 2013 on amendment of Public Finance Law and certain other acts - form no. 1789, Sejm RP, 7th term). Even prior to the aforementioned act amending Public Finance Law, there were proposals to introduce solutions enabling RACs' supervision over the realization of the recovery proceedings programmes in the local government sector entities (Gonet, 2013, p. 185-187).

Pursuant to Article 240 section 4 Public Finance Law, the union's decision-making body may adopt long-term financial forecast and the union's budget which fail to maintain relation specified in Articles 242-244 Public Finance Law in the period of realization of the recovery proceedings programme that has obtained a positive opinion by the RAC, however such failure to maintain relations may apply only to the payment of liabilities existing on the day of adopting the recovery proceedings programme. In such circumstances, the decision-making body shall retain authorisation to adopt the aforementioned resolutions. The type (content) of RAC's opinion is therefore important, as in the case of a positive opinion on the programme not being issued by the RAC, it is the RAC who shall adopt the union's budget (Decision by Voivodship Administrative Court in Szczecin, 2013). Both the negative opinion by RAC on the recovery proceedings programme and failure to develop such programme by the metropolitan union, pursuant to the provisions of Article 240a section 3 Public Finance Law, is considered an event justifying substitutive adoption of the union budget by the RAC. Following the adoption of the budget by the RAC, the union's assembly regains its competence regarding the budgetary matters (Resolution of RAC in Wrocław, 2015). Pursuant to Article 240a section 9 Public Finance Law, the amendment of union's budget adopted by the RAC without maintaining relations specified in Article 242-244 Public Finance Law may not result in increased degree of failure to maintain relations resulting from this budget.

\section{Final conclusions}

The scope and rules for RACs issuing opinions on the financial documents of the metropolitan union is comparable to the procedure of issuing opinions on such documents drawn in LGUs, metropolitan associations and county 
unions. The Act on Metropolitan Unions, except for one provision referring to RACs' issuing opinions o the conclusions of the audit commission of the acknowledgement of the fulfilment of duties by the union's board, does not contain any other provisions referring to the process of issuing RAC's opinion on the financial documents of the union.

Thus, the provisions of the Public Finance Law and Act on RAC shall apply. Moreover, Article 16 section 2 Metropolitan Union Act contains significant provisions - pursuant to this Article, provisions of chapter 7 Voivodship Self-Government Act entitled "Supervision over the activity of the voivodship self-government" shall apply accordingly to the supervision over the activity of metropolitan union. The RAC's opinions are not binding for the local government bodies, but in certain circumstances are considered as a form of supervision, along with confirmations and arrangements (Decision by Voivodship Administrative Court in Wrocław, 2006). Article 80 Voivodship Self-Government Act may be indicated in the context of RACs' opinion-making activity. It states that if the law requires that the validity of the decision made by the local government body depends on the opinion on that decisionissued by the other body, zsuch body shall make a statement no later than within 14 days from the day of serving this decision or its draft The quoted provision refes to an existing, specific resolution which is to be delivered to the other body in order to obtain an opinion (Decision by Voivodship Administrative Court in Szczecin, 2008). In the analysed situation, it is obligatory to serve the RAC, in order to obtain opinion, with various financial documents of the metropolitan union (draft resolutions, periodical information and reports, recovery proceedings programmes, other financial documents).

Metropolitan union is a public entity and a unit of a public finance sector to which specific solutions apply regarding the standards of planning and executing financial activity. Execution of financial economics by an entity of such legal status shall be made pursuant to and within the limits of applicable law. The opinions issued by RACs are mainly a form of preliminary control over the financial activity of the metropolitan union. In the cases where the metropolitan union's body - due to RAC's having issued a negative opinion - has to commence certain activities, such opinion may be qualified as a quasi-supervisory measure (e.g. negative opinion resulting in obligation to duly correct the long-term financial forecast and budgetary resolution in order to obtain standards set out in Articles 242-244 Public Finance Law). In one case, the negative opinion of the RAC may be categorised directly as a supervisory measure the RAC is entitled to, i.e. the negative opinion on the 
recovery proceedings programme, resulting in the union's assembly losing the authorisation to adopt the budget and leading to the substitutive adoption of the budget by RAC.

Moreover, the opinion-making activity of RACs is also an important source of gathering information about the events related to financial economics of the self-government sector entities. Pursuant to Article 10 Act on RACs, on the grounds of the results of the supervisory, monitoring and opinion-making activity, the RAC presents a report on the condition of financial economics of a given self-government sector entity, if it is neccessary to point out the repeated irregularities or threat to the execution of statutory tasks to local government bodies. The RAC's committee takes decision on drawing the report by means of a resolution, specifies its scope and term and appoints a member of the RAC's committee responsible for preparation of the draft report. The report may not be drawn on request of the other entity, e.g. the decision-making body of a self-government entity or a group of councillors (Grzegorzewski 2004, p. 6). Following the adoption of the report by the RAC's committee, the chairman of the RAC hands the report to the decision-making and executive bodies of the proper self-government entity (in case of the union, also to the union's bodies). The bodies of the entity may file objections to the report to the RAC's committee no later than within 30 days from the day of receiving the report. The RAC's committee dismisses the objections or meets the concerns and amends the report. The content of the report is subject to announcement in teleinformatic system.

\section{References}

Act of 27 August 2009 on Public Finance Law, consolidated text Dz.U. of 2016 item 1870 as amended.

Act of 5 June 1998 on District Self-Government, consolidated text Dz.U. of 2016 item 814 as amended.

Act of 5 June 1998 on Voivodship Self-Government, consolidated text Dz.U. of 2016 item 486 as amended.

Act of 6 September 2001 on access to public information, consolidated text Dz.U. of 2016, item 1764 as amended.

Act of 7 October 1992 on Regional Accounting Chambers, consolidated text Dz.U. of 2016 item 561 as amended.

Act of 8 March 1990 on Commune Self-Government, consolidated text Dz.U. of 2016 item 446 as amended. 
Act of 9 October 2015 on metropolitan unions, Dz.U. of 2015, item 1890 as amended.

Bańko M. ed. (2003). Wielki Słownik wyrazów obcych PWN. Warszawa: Wyd. Naukowe PWN SA.

Bańko M. ed. (2005). Wielki Słownik wyrazów bliskoznacznych PWN. Warszawa: Wyd. Naukowe PWN S.A.

Bańko M. ed. (2007). Słownik języka polskiego, v. 3. Warszawa: Wyd. Naukowe PWN.

Bitner M. (2016). Prawne instrumenty ograniczania deficytu budżetowego i długu publicznego jednostek samorządu terytorialnego. Warszawa: Wolters Kluwer.

Chruściel J., Kotowski J.(2012). Absolutoriumsamorządowew rozstrzygnięciach kolegiów regionalnych izb obrachunkowych w 2012 r. oraz w dotychczasowym orzecznictwie sądów administracyjnych. Finanse Komunalne, 11, 58-74.

Decision by Voivodship Administrative Court in Kielce, dated October 30, 2013, I SA/Ke 554/13, LEX no. 1426536.

Decision by Voivodship Administrative Court in Łódź dated December 4, 2015 , I SA/Łd 1232/15, Legalis no. 1388099.

Decision by Voivodship Administrative Court in Łódź dated December 4, 2015 , I SA/Łd 1231/15, Legalis no. 1388098.

Decision by Voivodship Administrative Court in Szczecin dated June 23, 2013, I SA/Sz 519/16, Legalis no. 1547130.

Decision by Voivodship Administrative Court in Szczecin dated October 29, 2015, I SA/OI 338/15, Legalis no. 1388235.

Decision by Voivodship Administrative Court in Szczecin, dated March 12, 2008, I SA/Ke 1160/07, LEX no. 505320.

Decision by Voivodship Administrative Court in Wrocław, dated June 21, 2006, IV SA/Wr 432/05, OwSS 2008, no. 1, p. 20.

Dolnicki B. (2016). Samorząd terytorialny. Warszawa: Wolters Kluwer.

Dubisz S. ed. (2003). Słownikjęzyka polskiego, v. 3. Warszawa: Wyd. Naukowe PWN.

Gonet W. (2013). Naprawa finansów jednostki samorządu terytorialnego. Warszawa: Difin.

Gorgol A. (2014a). Commentary on Article 238. In P. Smoleń (Ed.), Ustawa o finansach publicznych [Public Finance Law]. Comment. Warszawa: C.H. Beck.

Gorgol A. (2014b). Commentary on Article 246. In P. Smoleń (Ed.), Ustawa o finansach publicznych [Public Finance Law]. Commentary. Warszawa: C.H. Beck. 
Grzegorzewski P. (2004). Regionalne izby obrachunkowe w świetle nowelizacji ustawy o regionalnych izbach obrachunkowych z 24 lipca 2003 roku. Finanse Komunalne, 3, 5-15.

Jurewicz D. (2015). Opinie regionalnych izb obrachunkowych. In A. Borodo (Ed.), Słownik finansów samorządu terytorialnego. Toruń: Dom Organizatora. Leńczuk J. (2014). Comment on Article 230a. In P. Smoleń (Ed.), Ustawa o finansach publicznych [Public Finance Law]. Comment. Warszawa: C.H. Beck.

Ofiarska M., Ofiarski Z. (2013). Opinie regionalnych izb obrachunkowych jako narzędzie oddziaływania na organy jednostek samorządu terytorialnego. In Krawczyk R.P., Stec M. (Eds.), Samorząd - finanse - nadzór i kontrola. XXlecie regionalnych izb obrachunkowych. Warszawa: Wolters Kluwer.

Resolution of Minister of Finance of 10 January 2013 on long-term financial forecast for LGUs, consolidated text Dz.U. of 2015 item 92 as amended.

Resolution of RAC in Bydgoszcz dated June 4, 2004, XIV/16/04, LEX no. 1724745.

Resolution of RAC in Katowice, dated January 13, 2016, 9/1/2016, Legalis no. 1428686.

Resolution of RAC in Lublin dated June 26, 2012, 70/2012, OwSS 2013, no. 1, p. 106.

Resolution of RAC in Opole, dated August 8, 2012, 17/29/2012, „Nowe Zeszyty Samorządowe" 2012, no. 5, p. 87.

Resolution of RAC in Rzeszów dated August 9, 2011, XVII/3715/2011, Legalis no. 1259923.

Resolution of RAC in Warsaw dated May 25, 2011, 178/K/11, LEX no. 1726167. Resolution of RAC in Wrocław, dated February 18, 2015, 16/2016, Legalis no. 1370560.

Resolution of RAC in Zielona Góra dated September15, 2010, 299/2010, LEX no. 1725683.

Salachna J. M. (2010). Informacje oraz sprawozdania z wykonania budżetu jednostki samorządu terytorialnego. In Salachna J. M. (Ed.), Budżet i wieloletnia prognoza finansowa jednostek samorządu terytorialnego - od projektu do sprawozdania. Gdańsk: ODDK.

Salachna J. M. (2013). Commentary on Article 23. In Ruśkowski E., Salachna J.M. (Eds.), Finanse publiczne. Komentarz praktyczny. Gdańsk: ODDK.

Sawicka K. (2013a). Opinie regionalnej izby obrachunkowej dotyczące wieloletniej prognozy finansowej. In Miemiec W., Sawicka K., Miemiec M. (Eds.), Prawo finansów publicznych sektora samorządowego, Warszawa: Wolters Kluwer. 
Sawicka K. (2013b). Rola regionalnych izb obrachunkowych w procedurze uchwalania i kontroli wykonania budżetu jednostek samorządu terytorialnego. Przegląd Prawa i Administracji, 93, 49-71.

Srocki S. (2014). Wieloletnia prognoza finansowa jako instrument stabilizacji finansowej samorządu - zagadnienia prawne. Finanse Komunalne, 12, 5-14.

Walasik A. (2011). Wątpliwości dotyczące wieloletniej prognozy finansowej. Samorząd Terytorialny, 1-2, 43-50. 